\title{
A Review on Genus Saurauia: Chemical Compounds and their Biological Activity
}

\author{
Gunawan Pasaribu ${ }^{1, *}$, Emil Budianto ${ }^{2}$, Herry Cahyana ${ }^{2}$, Endang Saepudin²
}

Gunawan Pasaribu ${ }^{1, *}$, Emil Budianto ${ }^{2}$, Herry Cahyana ${ }^{2}$, Endang Saepudin ${ }^{2}$

'Postgraduated Student at Department of Chemistry, Faculty of Matematics and Natural Sciences, Universitas Indonesia, Depok, INDONESIA.

${ }^{2}$ Department of Chemistry, Faculty of Matematics and Natural Sciences, Universitas Indonesia, Depok, INDONESIA.

\section{Correspondence}

\section{Gunawan Pasaribu}

Postgraduated Student at Department of Chemistry, Faculty of Matematics and Natural Sciences, Universitas Indonesia, Depok, INDONESIA

E-mail: gun_pa1000@yahoo.com History

- Submission Date: 26-01-2020;

- Review completed: 18-02-2020.

- Accepted Date: 10-03-2020

DOI : 10.5530/pj.2020.12.97

Article Available online

http://www.phcogj.com/v12/i3

\section{Copyright}

(C) 2020 Phcogj.Com. This is an openaccess article distributed under the terms of the Creative Commons Attribution 4.0 International license.

\begin{abstract}
Introduction: Saurauia plant has been widely used to treat a variety of diseases suffered by villagers at various places in the world. These species are widely used traditionally by the community as antidiabetic and digestive problems' remedy. This paper will present various uses and researches ever carried out by researchers in the world on various types of the genus Saurauia. Methods: The Information was collected from scientific journals, books, and reports. Results: This review summarizes the existing information on several species of Saurauia in relation to their chemical compounds and biological activity. There are some of chemical compounds present and identified in Saurauia, i.e. $3 \beta$-hydroxy-Olean-12-en- 28oic acid; 3,19-Dihydroxyurs-12-en-28-oic acid; 3-hidroksi, 12(13)-en, 28-oleanolat acid; actinidin; several monoterpene lactones; seven triterpenoids, namely, cis-3-O-p-hydroxycinnamoyl ursolic acid; trans-3-O-p-hydroxycinnamoyl ursolic acid; ursolic acid; oleanolic acid; corosolic acid; maslinic acid; and $\beta$-amyrin; and two steroids, stigmasterol; and $\beta$-sitosterol. There are several biological activities afforded by Saurauia i.e. antioxidant activity, anti-cholesterol, antidiabetic activity, antihyperlipidemic, analgetic activity, antimicrobial activity, wound-healing activity and immunostimulatory activity.
\end{abstract}

Key words: Saurauia, Chemical compounds, Biological activity, Human disease remedy.

\section{INTRODUCTION}

Plants of the genus Saurauia are widely distributed in Indonesia. One species regarded as quite widely known is Saurauia bracteosa. This species grows widely in the Lake Toba's Catchment Area, located in North Sumatra, Indonesia. This species can be found all the way from Lumban Julu, Sipangan Bolon, Merek up to Sipiso-piso area. In the last two years there has been massive harvesting of Saurauia leaves because it is believed able to efficaciously cure various diseases. Many of the leaves are traded around the trans-Sumatra road.

"Pirdot/cep-cepan lembu" (traditional name) leave (Saurauia vulcani Korth) is one of woody plant species which have been used to cure diabetes in accordance with Karo's local perception/prudence. For such, dried leaves (5-8 pieces) are boiled in 1 liter of water to allow for the water to evaporate for particular duration such that half the volume of the aqueous mixture remains. After becoming cool, the supernatant (clear) portion of that half aqueous boiled-leaves can be consumed twice up to three times a day. ${ }^{1}$ Pirdot (Saurauia bracteosa DC) leaves have tested as herbal tea. ${ }^{2}$

Meanwhile, Saurauia roxburghii is an evergreen tree species belonging to the family Actinidiaceae. This plant species is widely distributed in the coastal forest and hill tracts of Bangladesh, and also found outside Bangladesh country such as Vietnam, Nepal, India, Myanmar, Thailand, Cambodia, Laos, China (including Taiwan), Japan, and Malaysia. On the other hand, this species is less frequently encountered in the greater districts' area of Sylhet, Chittagong, and Chittagong's Hill Tracts in Bangladesh. Further, the stems and leaves of these plants are extensively used as herbal medicines against numerous severe diseases like asthma, bronchitis, hepatitis B, ulcers, and central nerves depression; and also in large numbers for the treatment of boils, Eczema, Epilepsy, Fever, Gout, and Piles. ${ }^{3}$

The species of Saurauia nepaulensis is used as firewood in Sikkim, India. ${ }^{4}$ The other species, Saurauia elegans, is traditionally used as edible wild fruits in Benguet, Cordillera administrative region, the Philippines. ${ }^{5}$ In 2001, On, et al. reported the other species, Saurauia tristyla, in Bavi National Park, Vietnam. ${ }^{6}$

About Saurauia bracteosa, the phase (period) of flowering and fruiting of this species has been studied enormously. ${ }^{7}$ They reported that the period from flower initiation to fruit maturity of Saurauia bracteosa took 145 days in average. Flower initiation lasted for 16 days; small-bud stage occurred in 38 days; large-bud phase came about in 16 days; anthesis stage took 5 days in average; and fruit development would complete in 74 days.

Saurauia homotricha, a new species from montane forests of western Honduras and Nicaragua, is placed in the Central American series Gymnogynae Buscalioni and is most similar to Saurauia rubiformis Vatke, from which it differs most markedly in the type, length, and distribution of trichomes on the leaves and the abaxial surface of the sepals. ${ }^{8}$

Meanwhile, according to Silalahi, 2015, Saurauia vulcanii leaves are used for the remedy of diarrhea, 
gastrointestinal disorders, and injury in ethnomedicine by sub-ethnic Batak Simalungun, in North Sumatra Province, Indonesia. ${ }^{9}$ The other species, Saurauia laevigata, is Honduran medicinal plant that used as digestive (stomach ache, ulcers, etc.). ${ }^{10}$

Saurauia species have been tried painstakingly to be described in New Guinea for lengthy years; in that the first effort was attempted by Miquel in 1869 and the last by Takeuchi in 2008. Consequently, Saurauia in New Guinea have long ever since been considered as a 'difficult' group to work with mainly due to the lack of a solid and taxonomically sound generic framework around which new taxa can be added. There is no definite understanding of Saurauia's characters which are taxonomically significant. ${ }^{11}$

On the other hand, Saurauia rufescens B.J. Conn \& Damas (Actinidiaceae) is described as a new species originated from the West Sepik region of Papua New Guinea. There are several morphological features that could distinguish Saurauia rufescens from another species of Saurauia (called Saurauia excurrens). The former species has red-brown indumentum; branchlets, which are sparsely covered with indistinct lenticels (while the latter species, Saurauia excurrens is densely covered with distinct lenticels); leaf margin (in the dormer species) is indistinctly crenulated with a single trichome, terminating each crenulation (while in the latter, Saurauia excurrens is with margin serrate with teeth c. $1 \mathrm{~mm}$ long); and interestingly the flowers (of both Saurauia rufescens and Saurauia excurrens species) occur amongst the foliage. ${ }^{12}$ The spesies of Saurauia taylorii is a distinctive new species from The Kaijende Highlands of Papua New Guinea. ${ }^{13}$

Shu 2007 and He et.al., 2005 explained that there were several species of Saurauia that grow in China. Those are among others Saurauia griffithii, Saurauia miniata, Saurauia napaulensis, Saurauia erythrocarpa, Saurauia rubricalyx, Saurauia punduana, Saurauia thyrsiflora, Saurauia tristyla, Saurauia polyneura, Saurauia cerea, Saurauia yunnanensis, Saurauia macrotricha, and Saurauia sinohirsuta. ${ }^{14,15}$

Saurauia napulensis, the Nepalese plants, several of the plant derived piscicides currently used in fishery management in many countries were originally used by the natives to stun and harvest fish for human consumption. ${ }^{16}$

Two new species of Saurauia from Mexico are Saurauia madrensis and Saurauia cana. Saurauia madrensis occurs in cloud forests and Liquidambar forests of the Sierra Madre in Chiapas. Saurauia cana is found in wet forest habitats north of the trans-Mexican volcanic belt in the Sierra Madre Oriental. ${ }^{17}$ Therefore, there are four new species of Saurauia from South America i.e Saurauia multinervis, Saurauia Schultesiana, Saurauia mexiae and Saurauia chaparensis. ${ }^{18}$ The species of Saurauia homotricha, a new species from Honduras and Nicaragua. It is placed in the Central American series Gymnogynae Buscalioni and is most similar to Saurauia rubiformis Vatke, from which it differs most markedly in the type, length, and distribution of trichomes on the leaves and the abaxial surface of the sepals. ${ }^{8}$

However, there is another Saurauia species (i.e. Saurauia leeana) which was classified in IUCN Red list as the threatened species 2019. This species in its location is restricted to Ulu Sungai Sungai in Kota Marudu, Sabah. Saurauia leeana is known as a single collection from Ulu Sungai Sungai's area in Kota Marudu. The area is located within Kinabalu Park, a Totally Protected Area (TPA). The estimated area of occupancy (AOO) is as large as $4 \mathrm{~km}^{2}$ and so far is not in decline. The potential threat for this area is forest fire resulting from shifting agriculture which is carried out nearby and which could bring about negative impacts severely on the species (Saurauia) in the near future. Hence, it is assessed as Vulnerable D2. ${ }^{19}$

Similar to Saurauia leeana, according to Wihermanto 2004, Saurauia bracteosa DC., and Saurauia cauliflora DC (Saurauiaceae) are included in the endemic group of Java, further regarded as rare plants. These species are existed in the submontana zone and montane mountains in Java. ${ }^{20}$ Species Saurauia microphylla (a native species) is an endemic flora of Java Island and listed under the IUCN Red List of Threatened Species 2016 (World Conservation Monitoring Center 1998). ${ }^{21}$

In another related case, there are some particular properties of Saurauia vulcani and simplisia ever examined. Characterization of ethanol extract from Saurauia vulcani extracts and simplisia exhibited specific properties, i.e. water (moisture) content at $6.65 \%$ and $7.25 \%$ respectively; percentage of water-soluble extract was $23.55 \%$ and $64.25 \%$ respectively. Still related, levels of ethanol soluble extract and simplisia were $20.32 \%$ and $66.45 \%$ respectively; total ash content was $4.01 \%$ and $0.60 \%$ respectively; and acid-insoluble ash content was $0.88 \%$ and $0.48 \%$ respectively. ${ }^{22}$

\section{PHYTOCHEMICAL AND TOXICITY}

There was phytochemical activity conducted by Saurauia bracteosa flower extract. The methanol extract of Saurauia bracteosa flower contained particular chemical compounds such as phenolic compounds, flavonoids, alkaloids, steroids and saponins. In the methanol extract, total flavonoid content amounted to $11,140 \mathrm{mg} / \mathrm{kg} .{ }^{23}$ On the other hand, Kadji et.al, 2013 showed that results of maceration and soxhlet extraction on Saurauia bracteosa leaves brought out the leaf extract which also contained phenolic compounds, steroids, flavonoids, and saponins. $^{24}$

Maukar and Pontoh 2013 reported that there were phytochemical compounds and toxicity activity of Saurauia bracteosa. The toxicity expressed as the $\mathrm{LC}_{50}$ (lethal concentration) value was obtained through the analysis on Saurauia bracteosa leaves. As such, the obtained LC $_{50}$ value was equal to $37.30 \mathrm{ppm}$. Meanwhile, the phenolic, flavonoid, and tannin contents in the leaves were Saurauia bracteosa leaves $43.06 \%$, $6.52 \%$, and $17.91 \%$, respectively. ${ }^{25}$

Barcello also reported that Saurauia sp. (soybo), Saurauia elegans (uyok), and Saurauia sparsifolia (degway/sapuwan) contained steroids, saponin, flavonoid, polyphenol, and tannin. ${ }^{26}$

According to Salim et al. 2017, the dried Saurauia cauliflora leaves contained flavonoids, alkaloids, tannins, anthraquinone glycosides and steroids/triterpenoids. ${ }^{27}$ Results of phytochemical screening on simplisia and ethanol Saurauia vulcani extract were essentially similar. Both items showed the presence of flavonoid, glycosides, saponins, tannins and steroids/ triterpenoids ${ }^{22}$.

Muaja et al. 2013 have conducted phytocemical and Brine Shrimp Lethality Test on Saurauia bracteosa DC leaf extract. The leaf extract was further tested to examine its phenolic, flavonoid, and tannin contents. Results showed that Saurauia cauliflora leaf extract was regarded as toxic $\left(\mathrm{LC}_{50}: 35.4 \mathrm{ppm}\right)$. The contents of phenolic, flavonoid, and tannin compounds in the extract were $128 \mathrm{ppm}, 44.4 \mathrm{ppm}$ and $86.75 \mathrm{ppm}$, respectively. $^{28}$

Species of Saurauia roxburghii can be found in India as medicinal plant. ${ }^{40}$ Furthermore, Ahmed et al. 2015 reported in vivo the Brine Shrimp's lethal active compounds which were isolated from Saurauia roxburghii leaves. ${ }^{38} \mathrm{Th}^{\mathrm{LC}} \mathrm{L}_{50}$ data for various extracts, column fractions, three pure compounds of Saurauia roxburghii, and vincristine sulfate (VS) were shown in Table 1. The crude extracts and isolated pure compounds posed the potential cytotoxic activities which might provide support for some of their uses in ethnomedicine treatment.

\section{CHEMICAL COMPOUNDS}

Research results on the leaves of Saurauia vulcani Korth. plant were collected in Silangkitang Village, North Tapanuli, North Sumatera Province, Indonesia. ${ }^{34}$ They found two triterpenoid compounds as 
Table 1: $\mathrm{LC}_{50}$ data of Saurauia roxburghii leaf extract.

\begin{tabular}{cc}
\hline Extract samples & $\mathrm{LC}_{50}(\mu \mathrm{g} / \mathrm{mL})$ \\
\hline VS & 0.32 \\
Ethanol & 12.59 \\
n-hexane & 14.79 \\
Chloroform & 14.06 \\
Ethyl-acetate & 15.47 \\
H-13 & 11.75 \\
H-19 & 10.96 \\
Compound-1 & 4.37 \\
Compound-3 & 6.92 \\
Compound-4 & 11.88 \\
\hline
\end{tabular}

Remarks: VS: Vincristine sulphate (Std.); column fractions of H-13 and C-19 using n-Hexane and chloroform as extracting solvent, respectively.

anti-cholesterol agent, 3 $\beta$-hydroxy-Olean-12-en- 28-oic acid (1) and 3,19-Dihydroxyurs-12-en-28-oic acid (2). The chemical structure of compounds 1 and 2 was shown in Figure 2. Furthermore, Suparman et al. 2018 has characterized of Saurauia bracteosa extract compounds with IR and NMR spectroscopy. From the result of phytochemical test and characterization of secondary metabolite compound which successfully isolated is triterpenoid group compound. ${ }^{41}$

Two steroid compounds were isolated from the n-hexane extract of Saurauia roxburghii leaves. Based on the spectral analysis evidence using IR, 1H-NMR, and 13C-NMR devices, the chemical structures which were determined / identified turned out to be stigmasterol (1) and $\beta$-sitosterol (2), as presented in Figure $3 .^{3}$

Situmeang et al, 2018 reported a chemical compound which was isolated from Saurauia vulcani leaves where their host trees grew in Silangkitang-Sipoholon, North Tapanuli Regency. They used extract ethyl-acetate solvent to isolate the compound. They reported the compound which was isolated, could be identified as 3-hidroksi, 12(13)-en, 28-oleanolat acid (Figure 4). ${ }^{42}$

Further, the chemical composition in the essential oil that resulted from the hydro distillation on the air-dried roots of Saurauia lantsangensis $\mathrm{Hu}$ was such that it gave the oil with a dark yellowish color, whereby the yield reached $0.27 \%(\mathrm{w} / \mathrm{w})$. The GCMS analysis on the essential brought out the results that as many as 39 chemical components were detected, which in portion represented $96.41 \%$ of the oil. The essential oil was found out to be rich in oxygenated sesquiterpenes (36.24\%), esters $(17.50 \%)$, sesquiterpenes $(12.57 \%)$, and oxygenated monoterpenes (3.64\%). Major components of the oil were T-muurolol (13.85\%), followed in the decreasing order by consecutively acetophenone (7.46\%), $\alpha$-cadinol (6.26\%), methyl palmitate (5.36\%), $n$-hexadecanoic acid (4.31\%), torreyol (3.69\%), and isospathulenol (3.48\%). ${ }^{37}$

Chemical constituents in Saurauia excelsa plant species have been reported by particular researchers. They examined that Saurauia excelsa species was originated from Venezuela and belonged to the family Accinidaceae. It has been also reported that the species of this family contained actinidine (2-4) and several monoterpene lactones (2, $4,5)$ (Figure 5). The authors are quite willing to report the isolation of n-tricosyl alcohol and p-sitosterol from a petroleum ether extract; and anabasine from the ethanolic fraction. ${ }^{43}$

Ahmed et al, 2016 reported the presence of particular chemical constituents in Saurauia roxburghii leaves. Continuous chromatographic separation and purification on the crude chloroform and $n$-hexane extracts from the leaves yielded seven triterpenoids, i.e. cis-3-O- $p$ hydroxycinnamoyl ursolic acid (1), trans-3-O-p-hydroxycinnamoyl ursolic acid (2), ursolic acid (3), oleanolic acid (4), corosolic acid (5), maslinic acid (6), and $\beta$-amyrin (7); and two steroids, i.e. stigmasterol (8) and $\beta$-sitosterol (9). The configurations of these isolated pure compounds were elucidated by using spectroscopic analysis. ${ }^{4}$

\section{BIOLOGICAL ACTIVITY}

\section{Antioxidant activity}

Barcelo 2015 reported that the DPPH (Diphenyl-2-picrylhydrazyl) radical-scavenging activity conducted by consecutively Saurauia sp. (soybo), Saurauia elegans (uyok) and Saurauia sparsifolia (degway/ sapuwan) fruit was $86.40 \mathrm{ppm}^{26}$

According to Lisi et al 2017, the antioxidant activity conducted by Saurauia bracteosa flower extract. The antioxidant activity of the methanol flower extract as expressed by the $\mathrm{IC}_{50}$ value amounted to 128,573 ppm. ${ }^{23}$ On the other hand, Kadji et al., 2013 reported that the antioxidant activity conducted by Saurauia bracteosa leaves' extract (in both types of the extracts) afforded powerful antioxidant activity. The $\mathrm{IC}_{50}$ values of flower extract that resulted from the maceration and soxhlet extraction were $38,01 \mathrm{ppm}$ and $28,18 \mathrm{ppm}$, respectively. ${ }^{24}$

Furthermore, Zhu et al 2012 reported that the ethyl acetate extract of Saurauia lantsangensis exhibited an excellent DPPH radical-scavenging activity, which was higher than that of BHT (Butylated hydroxytoluene) at all the concentrations tested. At $50 \mu \mathrm{g} / \mathrm{ml}$ concentration, the highest percentage of DPPH radical-scavenging activity at $94.3 \%$ was observed in the ethyl acetate extract, which was significantly higher $(p<0.05)$ than that of BHT (68.3\%). From 0 to $100 \mu \mathrm{g} / \mathrm{ml}$ concentration, the DPPH radical-scavenging activity of the ethyl acetate extract remarkably increased in a dose-dependent manner but less did so when the concentration exceeded $50 \mu \mathrm{g} / \mathrm{ml}$. The methanol extract showed stronger DPPH free radical-scavenging activity than BHT, at 25 and $50 \mu \mathrm{g} / \mathrm{ml}$ concentrations. On the other hand, ethyl acetate extract and methanol extract exhibited an excellent superoxide anion radical-scavenging activity in a dose-dependent manner, which was higher than that of BHT. At $100 \mu \mathrm{g} / \mathrm{ml}$, the superoxide anion radical scavenging activities of the ethyl acetate extract, methanol extract, and BHT were $(92.4 \pm 3.2),(83.6 \pm 2.8)$, and $(76.7 \pm 3.3) \%$, respectively. ${ }^{37}$ Parts of plants used and their bioactivity are presented in Table 2 .

Lovena et al .2018 reported that the antioxidant activity value of the water extract from Saurauia vulcani IC $_{50}$ values was $22,9182 \pm 1.32 \mu \mathrm{g} /$ $\mathrm{mL}$, whereas the $\mathrm{IC}_{50}$ value of the produced-quercetin was $4.96 \pm 0.02$ $\mu \mathrm{g} / \mathrm{ml}$. These results showed that the ability of water extract from Saurauia vulcani leaves to capture free radicals was regarded as a strong antioxidant. This is because the water extract concentration lay in the range of $50-100 \mu \mathrm{g} / \mathrm{ml}$ concentration, which belonged to the strong category. ${ }^{31}$

\section{Anti-cholesterol}

Musa et al 2019 reported that the compounds as extracted from Saurauia vulcani leaves were evaluated for their anti-cholesterol activity test in accordance with the Liebermann-Burchard (LB) colorimetric assay. Compounds 1-2 (Figure 1) showed a remarkable anti-cholesterol 


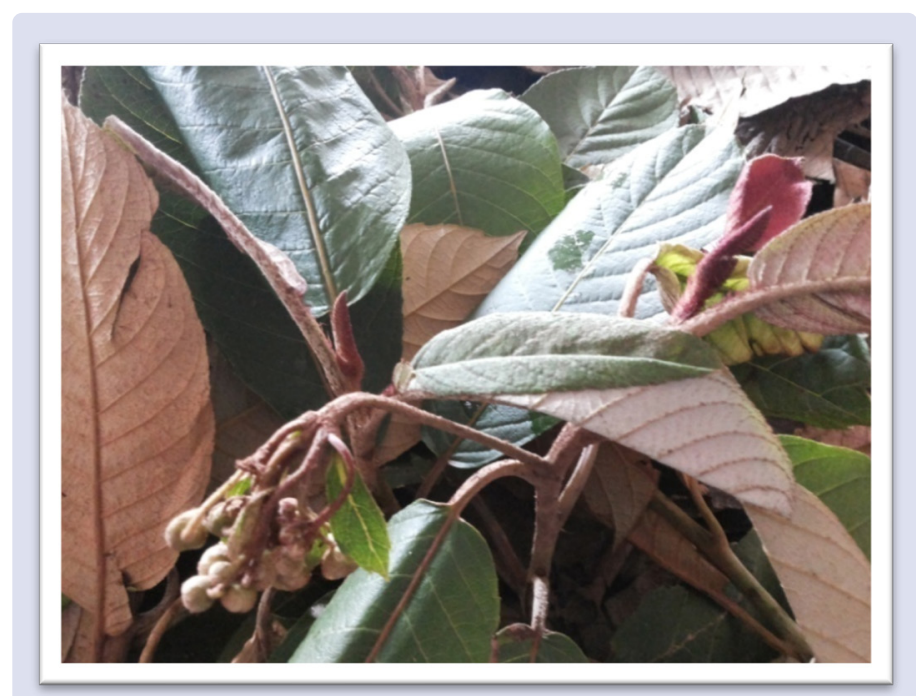

Figure 1: Saurauia vulcani leaves.

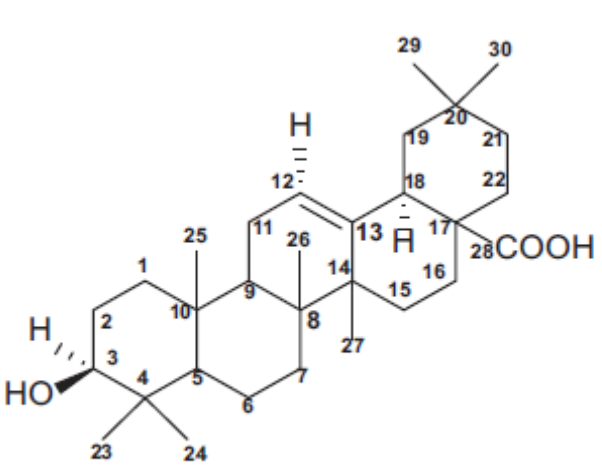

1

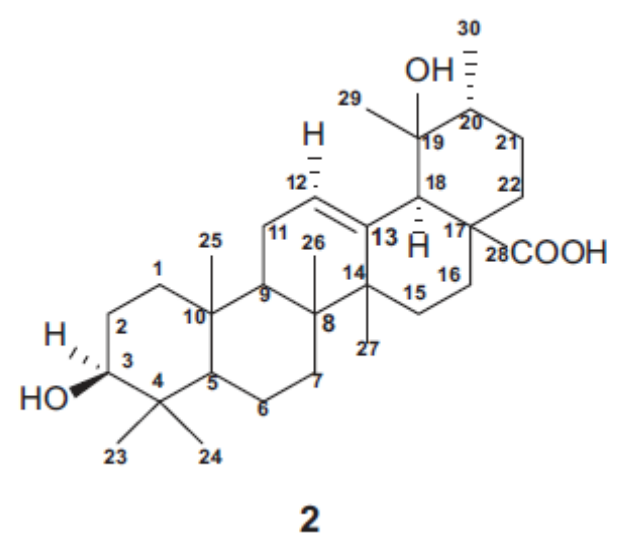

2

Figure 2: Chemical structure of Saurauia vulcani compound.

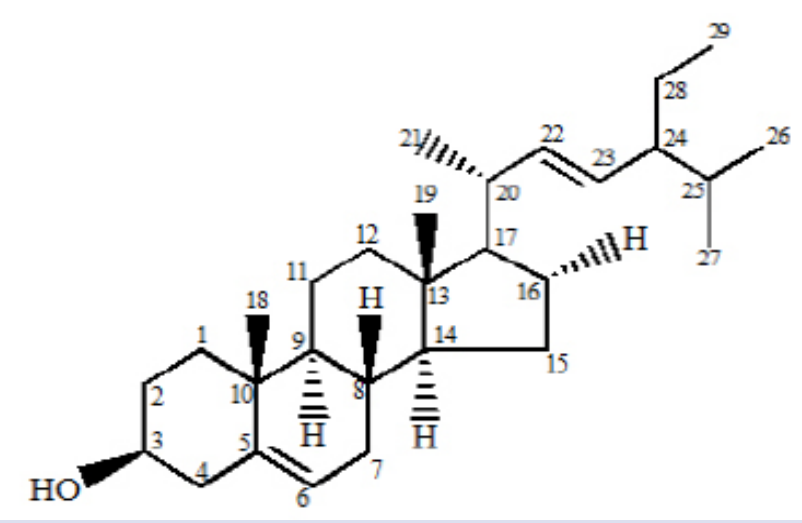

Figure 3: Chemical structure of Saurauia roxburghii compound; Stigmasterol (1) \& $\beta$-sitosterol (2). 


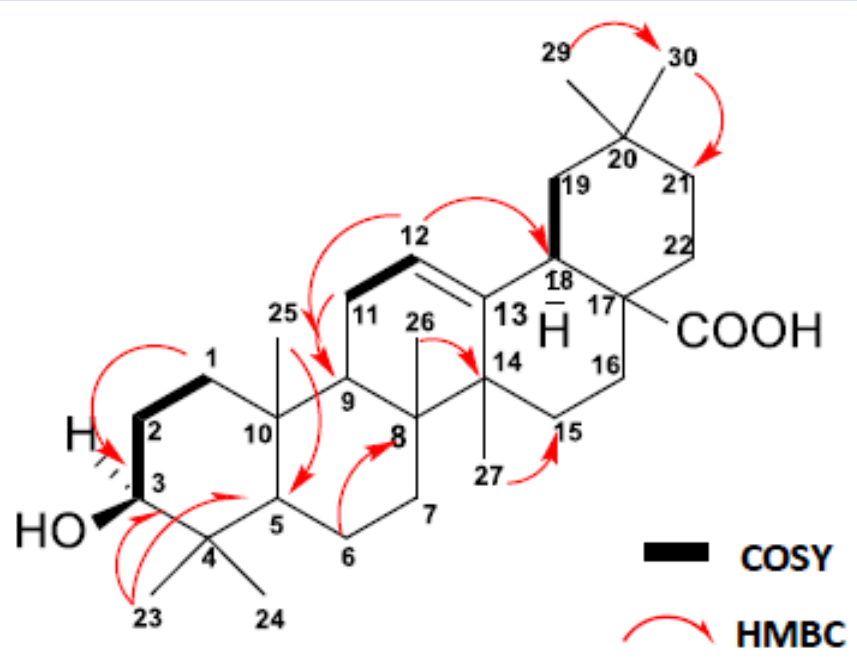

Figure 4: Chemical structure of 3-hidroksi, 12(13)-en, 28-oleanolat acid.

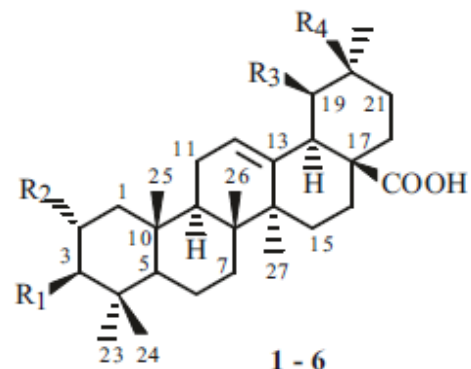<smiles>[Y]OC(=O)/C=C\c1ccc(O)cc1</smiles>

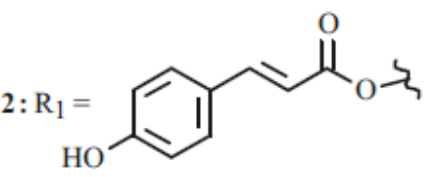

1, 2: $\mathrm{R}_{2}=\mathrm{R}_{4}=\mathrm{H}, \mathrm{R}_{3}=\mathrm{CH}_{3} ; 3: \mathrm{R}_{1}=\mathrm{OH}, \mathrm{R}_{2}=\mathrm{R}_{4}=\mathrm{H}, \mathrm{R}_{3}=\mathrm{CH}_{3}$

4: $\mathrm{R}_{1}=\mathrm{OH}, \mathrm{R}_{2}=\mathrm{R}_{3}=\mathrm{H}, \mathrm{R}_{4}=\mathrm{CH}_{3} ; 5: \mathrm{R}_{1}=\mathrm{R}_{2}=\mathrm{OH}, \mathrm{R}_{4}=\mathrm{H}, \mathrm{R}_{3}=\mathrm{CH}_{3}$

6: $\mathrm{R}_{1}=\mathrm{R}_{2}=\mathrm{OH}, \mathrm{R}_{3}=\mathrm{H}, \mathrm{R}_{4}=\mathrm{CH}_{3}$

Figure 5: Chemical structure of actinidine (2-4); and several monoterpene lactones $(2,4,5)$.

Table 2: Part of used of Saurauia species.

\begin{tabular}{|c|c|c|c|}
\hline No & Species & Part used & Activity \\
\hline 1 & Saurauia vulcani & Leaves & $\begin{array}{c}\text { Antidiabetic }{ }^{1,29,30,31,32,33,22,30} \\
\text { Antioxidant }^{31} \\
\text { Anticholesterol }^{34} \\
\text { Antihyperlipidemic }^{35} \\
\text { Wound-healing }^{32} \\
\text { Immunostimulatory }^{36}\end{array}$ \\
\hline 2 & $\begin{array}{c}\text { Saurauia elegans } \\
\text { Saurauia sparsifolia }\end{array}$ & Fruit & Antioxidant ${ }^{26}$ \\
\hline 3 & Saurauia bracteosa & $\begin{array}{l}\text { Flower } \\
\text { Leaves }\end{array}$ & $\begin{array}{l}\text { Antioxidant }{ }^{23} \\
\text { Antioxidant }^{24}\end{array}$ \\
\hline 4 & Saurauia lantsangensis & Leaves & $\begin{array}{c}\text { Antioxidant }^{37} \\
\text { Antimicrobial }^{37}\end{array}$ \\
\hline 5 & Saurauia cauliflora & Leaves & Analgetic $^{27}$ \\
\hline 6 & Saurauia roxburghii & Leaves & Antimicrobial $^{38}$ \\
\hline 7 & Saurauia scaberrinae & Leaves & Antimicrobial $^{39}$ \\
\hline
\end{tabular}


activity. Most importantly, raising concentration of the compounds 1-2 exhibited a dose-dependent manner. ${ }^{34}$

\section{Antidiabetic activity}

Sitorus and Satria 2018 used Saurauia vulcani Korth. leaves, which were taken from Tarutung area, located in North Sumatera, Indonesia. Antidiabetic assay used in this study was male rats. Results showed that significant reduction in blood glucose levels of the rats $(\mathrm{p}<0.001)$ occurred at the dosage $50 \mathrm{mg} / \mathrm{Kg} \mathrm{BW}^{29}$

According to Hutahaean et al. 2018 the effect of Saurauia vulcani leaves' extract on blood sugar levels in the alloxan-induced diabetic mice (Table 3). Results revealed that the leaves' extract exhibited the potential capability as antihyperglycemic. The effects as obtained were equivalent to the effects of antidiabetic metformin drug. ${ }^{30}$

According to Lovena et al, 2018, antidiabetic activity caused by inhibition of this enzyme activity assay occurred on water extract of Saurauia vulcani leaf. Results showed that the acarbose had the ability to inhibit the activity of $\alpha$-glucosidase with the $\mathrm{IC}_{50}$ values at 150.63 $\pm 0.25 \mu \mathrm{g} / \mathrm{mL}$. Meanwhile, the extract afforded the ability to inhibit the activity of $\alpha$-glucosidase with lower IC $_{50}$ value i.e. $75.56 \pm 1.07 \mu \mathrm{g} /$ $\mathrm{mL}$. Therefore, it can be inferred that the water extract exerted more significant capabilities in inhibiting the activity of a-glucosidase compared to those of acarbose. ${ }^{31}$

Anastasia et al 2018 reported that there occurred the effect of Saurauia vulcani in hyperglycemic rats. Results showed that administering of aqueous extract from Saurauia vulcani in hyperglycemia rats at the doses at consecutively $0.25 \mathrm{~mL}, 0.5 \mathrm{~mL}$ and $1.0 \mathrm{~mL}$ brought out significant effect $(P<0.05)$, and such dose dependency brought about the decrease in the rats' blood glucose levels when compared with the negative control. Strepzotosin increased the blood glucose level in rats by observing the rat's obvious weight loss that visibly occurred within 7-10 days. Consequently, this occurrence indicated that there happened the damage of the irreversible pancreatic langerhans. Aqueous extract of Saurauia vulcani, which was administered for 15 days, caused the decrease in rats' blood glucose levels, but in the negative control treatment it showed that the blood glucose levels were in the range 387$493 \mathrm{mg} / \mathrm{dL}$. From the test results hence it can be seen that the decrease in blood glucose levels began to visibly occur on day 3 . As such, the largest decrease in blood glucose levels occurred in aqueous extract of Saurauia vulcani at $1 \mathrm{~mL}$ dose. Similar decrease also came about in the same Saurauia vulcani 's extract but at lower doses (i.e. $0.5 \mathrm{~mL}$ and 0.25 $\mathrm{mL}$, respectively). ${ }^{32}$

The blood glucose rate of the mice treated with $200 \mathrm{mg} / \mathrm{kg}$ BW (113.4 $\mathrm{mg} / \mathrm{dl}$ ) pirdot (Saurauia vulcani) leaf extract significantly differed from that of the mice in the diabetes mellitus control group $(364.8 \mathrm{mg} / \mathrm{dl})$ $(\mathrm{p}<0.05)$. The ganglion cell layer of the retina increased by up to 7.59 $\mu \mathrm{m}$, which differed from that of the diabetes mellitus group $(3.67 \mu \mathrm{m})$ $(p<0.05)$ treated with $250 \mathrm{mg} / \mathrm{kg}$ BW pirdot leaf extract. The external plexiform layer increased to $17.88 \mu \mathrm{m}$, which differed from that of the diabetes mellitus group $(15.71 \mu \mathrm{m})(p<0.05)$ treated with $150 \mathrm{mg} / \mathrm{kg}$ BW pirdot leaf extract. The blood glucose rate obtained after treatment with pirdot leaf extract was lower than that of the diabetes mellitus control group. ${ }^{33}$

Sitorus 2015 reported the characterization on simplisia and ethanolic extract from Pirdot (Saurauia vulcani Korth) leaves, and study results of antidiabetic effect in the alloxan-induced diabetic mice. Ethanolic extract of Saurauia vulcani Korth leaves showed favorable results as antidiabetic effect, as indicated by significant depletion of blood glucose level in the alloxan-induced diabetic mice for ten days. Blood glucose level reduced by $55.11 \%$, with ethanolic extract of Saurauia vulcani Korth leaves $200 \mathrm{mg} / \mathrm{kg}$ body weight, compared to the level with metformin $50 \mathrm{mg} / \mathrm{kg}$ body weight only, which revealed the blood glucose level reduction by $47.76 \% .^{22}$

Hutahayan et al. 2018 reported that Saurauia vulcani leaves extracts reduced the glucose to normal. In alloxan-induced diabetic mice, area of corpus cavernosa decreased significantly $(p<0.05)$, and again Saurauia vulcani leaves extract decreased corpus cavernosa area to normal. The diameter of helicine artery follows the same trend. In sperm parameter assessment, sperm count in alloxan- induced diabetic mice decreased to $197 \times 105$, and in extract groups the sperm count were back to normal only in the highest dosage ( $338 \times 105)$. There were no significant different in sperm quality (motility, viability, and normal percentage). In general, the result confirmed that the antihyperglycemic effect of Saurauia vulcani leaves extract, recommended its potency in penile contractile tissue improvement in diabetes, nevertheless it seems to have no effect on sperm quality. ${ }^{35}$

\section{Antihyperlipidemic}

Hutahaean et al. 2018 reported that the effect of Saurauia vulcani leaves on antihyperlipidemic effect was still not conclusive. This is because the extract lowered the total cholesterol significantly, but inflicted no significant effect on triglyceride, marked the noticeable reduction in the LDL, but significantly decreased the HDL level..$^{30}$

\section{Analgetic activity}

According to Salim et al, 2017 reported the role of Saurauia cauliflora DC. leaves' extract as analgetic agent. Analgesic effect of the extract was evaluated by observing the response time of mices to infrared as pain inducer. Mice were grouped into six categories, which comprised: vehicle, antalgin $65 \mathrm{mg} / \mathrm{kgBW}$, and extracts at the dose of consecutively $500 \mathrm{mg} / \mathrm{kgBW}, 250 \mathrm{mg} / \mathrm{kgBW}, 125 \mathrm{mg} / \mathrm{kgBW}, 62,5 \mathrm{mg} / \mathrm{kgBW}$, whereby all were administered orally. The water content in the dried leaves' solid was $5.3 \%$. The analgesic test results showed that the leaves' extract at the dose of $250 \mathrm{mg} / \mathrm{kgBW}$ brought about strong analgesic effect which was similar to that of the same extract at $500 \mathrm{mg} / \mathrm{kgBW}$ and that of antalgin at $65 \mathrm{mg} / \mathrm{kgBW}^{27}$

\section{Antimicrobial activity}

Saurauia lantsangensis oil exhibited a promising antimicrobial effect which was determined by observing the diameters of inhibition zones (i.e. 13.3 - 16.2, 16.5 - 20.4, 13.5 - 16.6, and $16.5-22.7 \mathrm{~mm}$ ), respectively, along with their respective MIC values $(500-1000,125$ - 500, $250-500$, and $250-500 \mu \mathrm{g} / \mathrm{ml}$ ) against consecutively Gram-

Table 3: Effect of Saurauia vulcani leaves' extract on blood sugar level in the alloxan-induced mice.

\begin{tabular}{cccccc}
\hline \multirow{2}{*}{ Treatments } & \multicolumn{4}{c}{ Blood sugar level (mg/dL) on days } \\
\cline { 2 - 6 } & 0 & 3 & 10 & 267 & 17 \\
\hline K1 & $109.4 \pm 36.7 \mathrm{a}$ & $226.8 \pm 35.2 \mathrm{a}$ & $237.2 \pm 43.9 \mathrm{a}$ & $267.8 \pm 47 \mathrm{~b}$ & $292.4 \pm 74.9 \mathrm{~b}$ \\
K2 & $102.6 \pm 22.8 \mathrm{a}$ & $230.2 \pm 23.8 \mathrm{a}$ & $189 \pm 30.3 \mathrm{a}$ & $154 \pm 36.7 \mathrm{a}$ & $135 \pm 25.1 \mathrm{a}$ \\
P1 & $97.2 \pm 14.5 \mathrm{a}$ & $301.4 \pm 13 \mathrm{a}$ & $278.4 \pm 97.4 \mathrm{a}$ & $192 \pm 76.9 \mathrm{a}$ & $173 \pm 74.8 \mathrm{a}$ \\
P2 & $117.0 \pm 38.3 \mathrm{a}$ & $225.2 \pm 24.7 \mathrm{a}$ & $175.4 \pm 24.9 \mathrm{a}$ & $134.2 \pm 21.5 \mathrm{a}$ & $129.8 \pm 23.4 \mathrm{a}$ \\
P3 & $122.4 \pm 15 \mathrm{a}$ & $279.8 \pm 58.8 \mathrm{a}$ & $191.2 \pm 41.5 \mathrm{a}$ & $156 \pm 27.9 \mathrm{a}$ & $134.4 \pm 41.7 \mathrm{a}$ \\
\hline
\end{tabular}

Remarks: Different superscripts mean statistically different $(P<0.05)$. 
Table 4: In vitro antibacterial activity conducted by Saurauia roxburghii.

\begin{tabular}{|c|c|c|c|c|c|c|c|c|c|c|c|c|c|}
\hline \multirow{2}{*}{ Name of the bacteria } & \multicolumn{4}{|c|}{$500\left(\mu \mathrm{g} \mathrm{disc}^{-1}\right)$} & \multicolumn{5}{|c|}{$400\left(\mu \mathrm{g} \mathrm{disc}^{-1}\right)$} & \multirow{2}{*}{ Com-1 } & \multirow{2}{*}{ Com-3 } & \multirow{2}{*}{ Com-4 } & \multirow{2}{*}{ Kanamycin } \\
\hline & Et & $\mathrm{H}$ & $\mathrm{Ch}$ & EA & $\mathrm{H}-13$ & $\mathrm{C}-15$ & C-19 & $\mathrm{E}-18$ & E-24 & & & & \\
\hline \multicolumn{14}{|l|}{ Gram positive } \\
\hline B. cereus & $16 \pm 1$ & $10 \pm 1$ & $13 \pm 1$ & $8 \pm 2$ & $8 \pm 1$ & $9 \pm 1$ & $10 \pm 1$ & $9 \pm 1$ & $12 \pm 1$ & $11 \pm 1$ & $14 \pm 1$ & $13 \pm 1$ & $34 \pm 1$ \\
\hline B. megaterium & $15 \pm 1$ & - & $13 \pm 1$ & - & - & $7 \pm 1$ & $9 \pm 1$ & - & - & $8 \pm 1$ & $9 \pm 1$ & $14 \pm 1$ & $34 \pm 1$ \\
\hline B. subtilis & $16 \pm 2$ & $12 \pm 1$ & $14 \pm 1$ & $10 \pm 1$ & $9 \pm 1$ & $9 \pm 2$ & $8 \pm 1$ & $8 \pm 1$ & $12 \pm 1$ & $12 \pm 1$ & $16 \pm 1$ & $15 \pm 1$ & $32 \pm 2$ \\
\hline S. Aureus & $18 \pm 2$ & $11 \pm 1$ & $14 \pm 1$ & $8 \pm 1$ & $8 \pm 1$ & $8 \pm 1$ & $10 \pm 1$ & $12 \pm 1$ & $10 \pm 1$ & $12 \pm 1$ & $14 \pm 1$ & $16 \pm 1$ & $35 \pm 1$ \\
\hline B. Polymyxa & $16 \pm 1$ & $10 \pm 1$ & - & $8 \pm 1$ & $10 \pm 1$ & - & - & - & - & $14 \pm 1$ & $12 \pm 1$ & $15 \pm 1$ & $33 \pm 1$ \\
\hline S. pneumoniae & $16 \pm 1$ & $12 \pm 1$ & $9 \pm 2$ & - & - & - & - & - & - & $12 \pm 1$ & $8 \pm 1$ & $16 \pm 1$ & $34 \pm 1$ \\
\hline M. tuberculosis & $22 \pm 1$ & $13 \pm 1$ & $20 \pm 2$ & $9 \pm 2$ & $10 \pm 2$ & $10 \pm 2$ & $12 \pm 2$ & $9 \pm 1$ & $12 \pm 1$ & $20 \pm 2$ & $16 \pm 2$ & $20 \pm 2$ & $31 \pm 2$ \\
\hline \multicolumn{14}{|l|}{ Gram negative } \\
\hline E. coli & $18 \pm 2$ & $13 \pm 2$ & $16 \pm 1$ & $12 \pm 1$ & $14 \pm 2$ & $10 \pm 1$ & $8 \pm 1$ & $7 \pm 1$ & $14 \pm 2$ & $12 \pm 1$ & $15 \pm 1$ & $12 \pm 1$ & $35 \pm 1$ \\
\hline Klebsiella sp & $14 \pm 1$ & $9 \pm 1$ & $12 \pm 1$ & $7 \pm 1$ & $10 \pm 1$ & - & - & - & - & $9 \pm 1$ & $15 \pm 2$ & $13 \pm 1$ & $32 \pm 2$ \\
\hline Proteus sp & $14 \pm 1$ & $8 \pm 2$ & $12 \pm 1$ & $8 \pm 1$ & - & - & - & - & - & - & $11 \pm 1$ & $14 \pm 1$ & $30 \pm 3$ \\
\hline S. typhi & $15 \pm 1$ & - & $13 \pm 2$ & $10 \pm 2$ & - & - & - & - & - & $13 \pm 1$ & - & - & $33 \pm 1$ \\
\hline S. sonnei & $14 \pm 1$ & $7 \pm 2$ & $15 \pm 1$ & $7 \pm 1$ & $10 \pm 1$ & $10 \pm 1$ & $13 \pm 1$ & $7 \pm 1$ & $12 \pm 1$ & - & $12 \pm 1$ & $13 \pm 1$ & $34 \pm 1$ \\
\hline P. aureus & $18 \pm 2$ & $9 \pm 1$ & $16 \pm 1$ & $10 \pm 1$ & - & $7 \pm 1$ & $8 \pm 1$ & $14 \pm 2$ & $10 \pm 1$ & $12 \pm 1$ & - & $16 \pm 1$ & $34 \pm 1$ \\
\hline V. cholera & $14 \pm 1$ & - & $13 \pm 1$ & - & - & $9 \pm 1$ & $8 \pm 2$ & - & - & $8 \pm 1$ & $10 \pm 1$ & $12 \pm 1$ & $31 \pm 2$ \\
\hline
\end{tabular}

Remarks: Et: Ethanol extract, He: n-hexane extract, Ch: Chloroform, EA: Ethyl acetate extract, column fractions (H-13, C-15, C-19, E-18 and E-24) of various extract and three pure compounds $(1,3,4)$, NA: No activity.

negative bacteria (Pseudomonas aeruginosa, Escherichia coli), Grampositive bacteria (Bacillus subtilis, Staphylococcus aureus), and a yeast (Hansenula anomala). ${ }^{37}$

Ahmed et al 2015 reported in vitro the role of antibacterial activity isolated from the leaves of Saurauia roxburghii (Table 4). The crude extracts and isolated pure compounds of the leaves posed the potential antibacterial activities which might provide support for some of their uses in ethnomedicine treatment. ${ }^{38}$

Phoma sp. was an endophyte of the plant Saurauia scaberrinae, collected in Papua New Guinea. The isolated compound (Phomodione 4) showed activity against $S$. aureus (MIC of $1.6 \mathrm{lg} / \mathrm{mL}$ ), P. ultimum $(4-5 \mathrm{lg} / \mathrm{mL}$ ), S. sclerotiorum $(3-5 \mathrm{lg} / \mathrm{mL})$ and $R$. solani $(5-8 \mathrm{lg} / \mathrm{mL})$. As reference, Cercosporamide that biosynthesized by the Phoma $s p$. endophytic isolate showed activity against $\mathrm{S}$. aureus (MIC of $2 \mathrm{lg} / \mathrm{mL}$ ), $P$. ultimum (3-4 $\mathrm{lg} / \mathrm{mL})$, S. sclerotiorum $(5-8 \mathrm{lg} / \mathrm{mL})$ and $R$. solani $(8-10 \mathrm{lg} / \mathrm{mL}){ }^{39}$

Yu, et al 2010 reported that Pestalachloride A and pestalachloride B are the novel antibiotics isolated from Pestalotiopsis adusta of Saurauia scaberrinae. It has antifungal activity towards plant pathogens such as Verticillium aiboatrum, Gibberella zeae and Fusarium culmorum. ${ }^{45}$

\section{Wound-healing activity}

Anastasia et al 2018 reported the role of Saurauia vulcani as woundhealing agent. Results of this study indicated that oral administering of aqueous extract from Saurauia vulcani, Korth leaves could speed up the healing process of hyperglycemia wounds. Related with such, macroscopic findings indicated the reduction in the wound size on the 3rd day to 15th day compared to the negative control and positive control. Those macroscopic findings therefore indicated the positive effects of the leaves' extract on the process of wound healing. ${ }^{32}$

\section{Immunostimulatory Activity}

Saurauia vulcani Korth. leaves has a potential immunostimulant activity which the parameter showed the enhancement of erthrocyte value and lymphocyte. It was also obtained a good histologic spleen. ${ }^{36}$

\section{CONCLUSION}

There were some of the chemical compounds in Saurauia species that could be identified, i.e. 3 $\beta$-hydroxy-Olean-12-en- 28-oic acid;
3,19-Dihydroxyurs-12-en-28-oic acid; 3-hidroksi, 12(13)-en, 28-oleanolat acid; actinidin; several monoterpene lactones; seven triterpenoids, namely, cis-3-O-p-hydroxycinnamoyl ursolic acid; trans-3-O-p-hydroxycinnamoyl ursolic acid; ursolic acid; oleanolic acid; corosolic acid; maslinic acid; and $\beta$-amyrin; and two steroids, stigmasterol; and $\beta$-sitosterol. Further, there were several biological activities afforded by Saurauia, i.e. antioxidant activity, anticholesterol, antidiabetic activity, antihyperlipidemic, analgetic activity, antimicrobial activity, wound-healing activity and immunostimulatory activity.

\section{CONFLICTS OF INTEREST}

The authors have declared no competing interest.

\section{REFERENCES}

1. Situmorang, R. O. P., Harianja, A. H. \& Silalahi, J. Karo's Local Wisdom : The Use of Woody Plants for Traditional Diabetic Medicines. Indones. J. For. Res. 2, 121-131 (2015).

2. Situmorang, R. \& Sunandar, A. Pirdot (Saurauia bracteosa DC) Leaf Processing Technique for Making Herbal Tea. in International Cobference on Forest Products (2019). doi:10.1088/1755-1315/359/1/012004

3. Ahmed, Y. et al. Isolation of steroids from n-hexane extract of the leaves of Saurauia roxburghii. Int. Food Res. J. 20, 2939-2943 (2013)

4. Chettri, N. \& Sharma, E. A scientific assessment of traditional knowledge on firewood and fodder values in Sikkim, India. For. Ecol. Manage. 257, 2073-2078 (2009).

5. Chua-barcelo, R. T. Ethno-botanical survey of edible wild fruits in B enguet Cordillera administrative region, the Philippines. Asian Pac. J. Trop. Biomed. 4 S525-S538 (2014)

6. On, T. Van et al. A survey of medicinal plants in BaVi National Park, Vietnam methodology and implications for conservation and sustainable use. Biol. Conserv. 97, 295-304 (2001).

7. Ali, C. \& Aminah, A. Flower and Fruit Development of Pirdot (Saurauia bracteosa DC .) at Aek Nauli Arboretum. J. Penelit. Hutan Tanam. 14, 103-114 (2017).

8. Pool, A. Saurauia homotricha (Actinidiaceae), a New Species from Honduras and Nicaragua. Novon 8, 280-282 (1998).

9. Silalahi, M., Supriatna, J. \& Walujo, E. K. O. B. Local knowledge of medicinal plants in sub-ethnic Batak Simalungun of North Sumatra, Indonesia. BIODIVERSITAS 16, 44-54 (2015).

10. Lentz, D. L. et al. Antimicrobial properties of Honduran medicinal plants. J. Ethnopharmacol. 63, 253-263 (1998)

11. Briggs, M. Saurauia ( Actinidiaceae) of New Guinea : current status, future plans. Gard. Bull. Singapore 63, 77-82 (2011). 
12. Conn, B. J. \& Damas, K. Q. A new species of Saurauia (Actinidiaceae) from Papua New Guinea. Telopea J. Plant Syst. 15, 9-12 (2013).

13. Takeuchi, W. SAURAUIA TAYLORII (ACTINIDIACEAE), A DISTINCTIVE NEW SPECIES FROM THE KAIJENDE HIGHLANDS OF PAPUA NEW GUINEA W. BLUMEA 53, 335-340 (2008)

14. Shu, shui dong ge. SAURAUIA Willdenow, Ges. Naturf. Freunde Berlin Neue Schriften 3: 407.1801 ['Saurauja'], nom. cons. Flora of China 12, 356-360 (2007).

15. He, Z., Li, J., Cai, Q. \& Wang, Q. The cytology of Actinidia, Saurauia and Clematoclethra (Actinidiaceae). Bot. J. Linn. Soc. 147, 369-374 (2005).

16. Kulkkattolickal, A. T. PISCICIDAL PLANTS OF NEPAL: PRELIMINARYTOXICITY SCREENING USING GRASS CARP (CTENOPHARYNGODON IDELLA) FINGERLINGS. J. Ethnophannacology 21, 1-9 (1987).

17. Keller, B. T. \& Breedlove, D. E. Two New Species of Saurauia (Actinidiaceae) from Mexico. Syst. Bot. 6, 65-73 (1981).

18. Djaja D. Soejarto. FOUR NEW SPECIES OF SAURAUIA FROM SOUTH AMERICA. Botanical Museum Leaflets 22, (1969).

19. Nilus, R. et al. Saurauia leeana. The IUCN Red List of Threatened Species 2019. IUCN Red List Threat. Species 2019 e.T136619735A136620145 (2019). doi:10.2305/IUCN.UK.2019-2.RLTS.T136619735A136620145.en

20. Wihermanto. Dispersi Asosiasi dan Status Populasi Tumbuhan Terancam Punah di Zona Submontana dan Montana Taman Nasional Gunung GedePangrango Dispersion pattern interspecific association and population status of threatened. B I O D IVER S ITA S 5, 17-22 (2004).

21. Dewi, S. P. \& Syamsudin, T. S. Data in brief Dataset on the reproductive period of three local species in a tropical sub-mountainous forest. Data Br. J. 25, 1-4 (2019).

22. Sitorus, P. Characterization Simplisia and Ethanolic Extract of Pirdot (Saurauia Vulcani, Korth ) Leaves and Study of Antidiabetic Effect in Alloxan Induced Diabetic Mice. Int. J. ChemTech Res. 8, 789-794 (2015).

23. Lisi, A. K. F., Runtuwene, M. R. J. \& Wewengkang, D. S. Uji Fitokimia dan Aktivitas Antioksidan dari Ekstrak Metanol Bunga Soyogik (Saurauia bracteosa DC.). PHARMACON J. IIm. Farm. - UNSRAT 6, 53-61 (2017).

24. Kadji, M. H., Runtuwene, M. R. J. \& Citraningtyas, G. Uji Fitokimia dan Aktivitas Antioksidan dari Ekstrak Etanol daun Soyogik (Saurauia bracteosa DC). PHARMACON J. IIm. Farm. - UNSRAT 2, 13-18 (2013).

25. Maukar, M. A. \& Pontoh, J. Fitochemistry Content Analysis of Toxicity Test of Methanol Extract of Soyogik Leave (Saurauia bracteosa DC) Using Maseration Method. J. IIm. Sains 13, 98-101 (2013).

26. Barcelo, R. Phytochemical Screening and Antioxidant Activity of Edible Wild Fruits in Benguet, Cordillera Administrative Region, Philippines. Electron. J. Biol. 11, 80-89 (2015).

27. Salim, E., Fatimah, C. \& Fanny, D. Y. ANALGETIC ACTIVITY OF CEP-CEPAN Saurauia cauliflora DC .) LEAVES EXTRACT. J. Nat. 17, 31-38 (2017).

28. Muaja, A. D., Koleangan, H. S. J. \& Runtuwene, M. R. J. Uji Toksisitas dengan Metode BSLT dan Analisis Kandungan Fitokimia Ekstrak Daun Soyogik (Saurauia bracteosa DC) dengan Metode Soxhletasi. J. MIPA UNSRAT ONLINE 2, 115-118 (2013).
29. Sitorus, P. \& Satria, D. HYPOGLYCEMIC ACTIVITY OF ETHANOLIC EXTRACT OF SAURAUIA VULCANI KORTH. LEAVES. Asian J. Pharm. Clin. Res. 11, 35-36 (2018).

30. Hutahaean, S., Tanjung, M., Sari, D. P. \& Ningsih, V. E. Antihyperglycemic and Antihyperlipidemic Effects of Pirdot (Saurauia vulcani Korth.) Leaves Extract in Mice. IOP Conf. Ser. Earth Environ. Sci. 130, (2018).

31. Lovena, T. N., Harahap, U., Sitorus, P. \& Satria, D. Antioxidant activity and $\alpha$ -glucosidase inhibition effect of water extract of Saurauia vulcani Korth leaves. J. Innov. Pharm. Biol. Sci. 5, 47-51 (2018).

32. Anastasia, G., Sitorus, P. \& Satria, D. Wound Healing Activity of Saurauia vulcan Korth Aqueous Leaves Extract Evaluation on Excision Wound in Hyperglycemia Rats. J. Innov. Pharm. Biol. Sci. 5, 52-57 (2018).

33. Hutapea, A., Hutahaean, S. \& Ilyas, S. Influence of Pirdot Leaf (Saurauia vulcani , Korth.) Extract on the Blood Glucose Rate and Histologic Description of the Retina of Male Mice (Mus musculus strain DDW). Asian J. Pharm. Clin. Res. 11, 389-392 (2018).

34. Musa, W. J. A., Situmeang, B. \& Sianturi, J. Anti-cholesterol triterpenoid acids from Saurauia vulcani Korth. (Actinidiaceae). Int. J. Food Prop. 22, 1439-1444 (2019).

35. Hutahaean, S., Banjarnahor, R. D., Darsini, P., llyas, S. \& Sabri, E. The effect of Saurauia vulcani Korth. leaves extract on penile corpus cavernosa microstructure and the quality of sperm in alloxan-induced diabetic mice. in SEMIRATA- International Conference on Science and Technology 1-7 (2018) doi:10.1088/1742-6596/1116/5/052030

36. Sinaga, E., Ilyas, S., Hutahaean, S. \& Sitorus, P. Immunostimulatory Activity from Pirdot Leaves Ethanolic Extract ( Saurauia vulcani Korth .) in Rats ( Rattus norvegicus ) Immunostimulatory Activity from Pirdot Leaves Ethanolic Extract ( Saurauia vulcani Korth .) in Rats ( Rattus norvegicus ). (2019). doi:10.1088/17551315/305/1/012082

37. Zhu, L., Zhu, S. \&Tian, Y. Antioxidant and Antimicrobial Activities of Essential Oil and Extracts of Saurauia lantsangensis Hu Root. A J. Biosci. 67, 282-290 (2012).

38. Ahmed, Y., Yaakob, Z., Akhtar, P., Rahman, M. \& Islam, F. In vitro Antibacteria and in vivo Brine Shrimp Lethal Active Compounds Isolated from the Leaves of Saurauia roxburghii. Int. J. Pharmacol. 1-7 (2015). doi:10.3923/ijp.2015.In

39. Martinez-Klimova, E., Rodríguez-peña, K. \& Sánchez, S. Endophytes as sources of antibiotics. Biochem. Pharmacol. 134, 1-17 (2017).

40. Shil, S., Choudhury, M. D. \& Das, S. Indigenous knowledge of medicinal plants used by the Reang tribe of Tripura state of India. J. Ethnopharmacol. 152, 135141 (2014).

41. Suparman, A. R., Kadarusman, M. \& Situmeang, B. SENYAWA TRITERPENOID DARI TUMBUHAN PIRDOT ( Sauralia. J. ITEKIMA 3, 12-19 (2018).

42. Situmeang, B., Suparman, A. R., Kadarusman, M., Parumbak, S. \& Herlina, T. Isolation of Triterpenoid Compound from Ethyl Acetate Extract of Pirdot. J. Kim Val. 4, 93-97 (2018).

43. Teixeira, M. I. \& Garbanio, J. A. Chemical Constituents of Saurauia excelsa. J. Nat. Prod. 47, 390-291 (1984).

44. Ahmed, Y., Akhtar, P., Rahman, S. \& Yaakob, Z. Chemical Constituents of Saurauia roxburghii. Chem. Nat. Compd. 52, 953-955 (2016).

45. Yu, H. et al. Recent developments and future prospects of antimicrobial metabolites produced by endophytes. Microb. Res. 165, 437-449 (2010). 


\section{GRAPHICAL ABSTRACT}

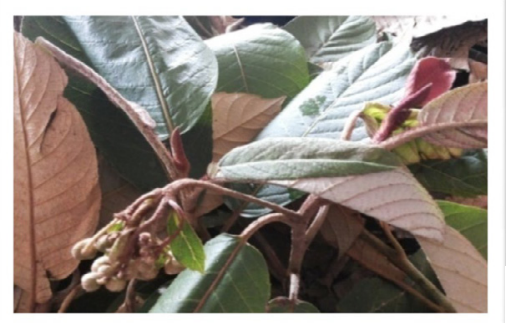

Saurauia sp.

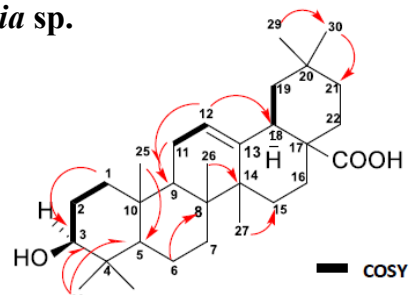

3-hidroksi, 12(13)-en, 28-oleanolat acid

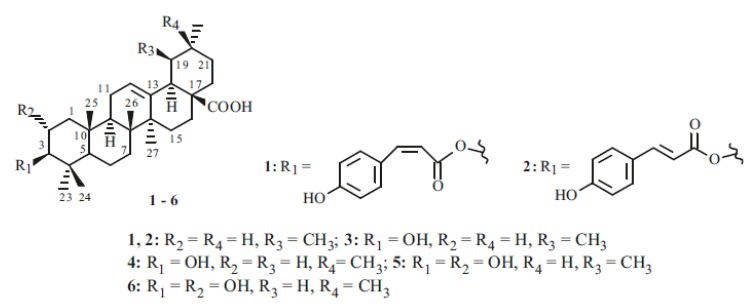

Actinidine (2-4); and several monoterpene lactones $(2,4,5)$
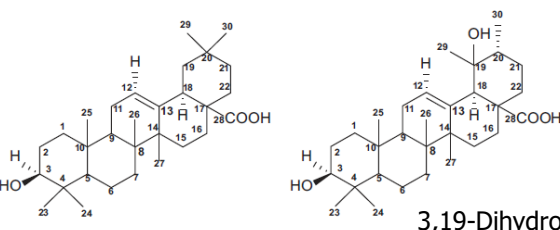

3,19-Dihydroxyurs-12-en-28-oic acid

3ß-hydroxy-Olean-12-en- 28-oic acid

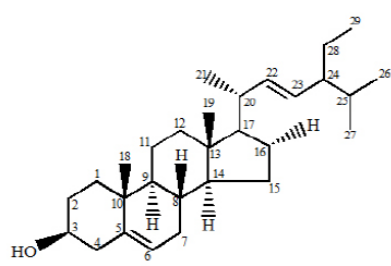

Stigmasterol

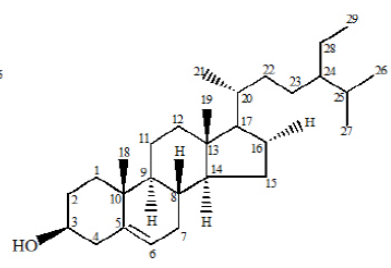

$\beta$-sitosterol
Bioactivity: antioxidant activity, anti-cholesterol, antidiabetic activity, antihyperlipidemic, analgetic activity, antimicrobial activity, wound-healing activity and immunostimulatory activity.

\section{ABOUT AUTHORS}

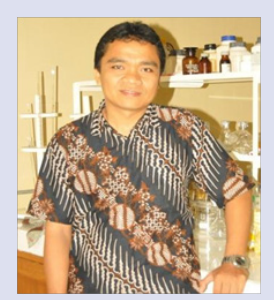

Gunawan Pasaribu: (M.Sc) is a Doctoral student at the Department of Chemistry, Faculty of Matematics and Natural Sciences, Universitas Indonesia, Depok, Indonesia. He is a researcher at Forest Products Research and Development Center, The Ministry of Environment and Forestry Republic of Indonesia.

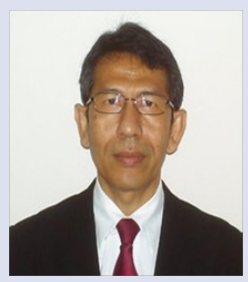

Emil Budianto: (Dr.rer.nat) is a Lecturer and Researcher at the Department of Chemistry, Faculty of Matematics and Natural Sciences, Universitas Indonesia, Depok, Indonesia.

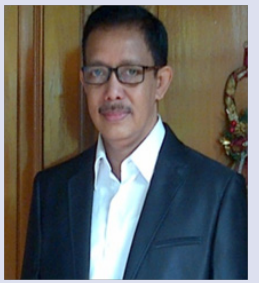

Herry Cahyana: (Ph.D) is a Lecturer and Researcher at the Department of Chemistry, Faculty of Matematics and Natural Sciences, Universitas Indonesia, Depok, Indonesia. 


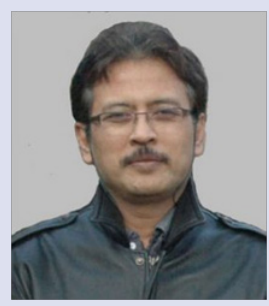

Endang Saepudin: (Ph.D) is a Lecturer and Researcher at the Department of Chemistry, Faculty of Matematics and Natural Sciences, Universitas Indonesia, Depok, Indonesia.

Cite this article: Pasaribu G, Budianto E, Cahyana H, Saepudin E. A Review on Genus Saurauia: Chemical Compounds and their Biological Activity. Pharmacogn J. 2020;12(3):657-66. 